\title{
Problem-Based Learning as a Solution to Textbook Style Analysis in Sociolinguistic Studies in Student Journal Articles
}

\author{
Agusniar D. Savitri ${ }^{1, *}$ Kisyani-Laksono ${ }^{1}$ Mukhzamilah $^{2}$ \\ 1,2 Universitas Negeri Surabaya, Indonesia \\ "Corresponding author.Email: agusniarsavitri@unesa.ac.id
}

\begin{abstract}
Not all sociolinguistic articles present the results of the analysis well, especially articles written by students. Most of the analysis is done by adjusting the data to the theory or in this paper. It is called textbook-style analysis. Problembased learning is considered to be a solution to these problems. This study aims to present an analysis of textbook-style in student journal articles and problem-based learning as a solution to overcome this. The data sources for this study are student journal articles with the topic focusing on sociolinguistics studies and students who program sociolinguistic courses. The method used is the method of documentation and observation. First, the results revealed that the analysis of textbook-style by students is caused by students' inability to understand sociolinguistic data analysis methods and a misunderstanding that considers data exposure in sociolinguistic textbooks as a way to analyze data. Second, problembased learning can improve students' ability to find sociolinguistic problems in the initial data; classify and compare data; analyze according to theory; and conclude the results.
\end{abstract}

Keywords: Textbook style analysis, Problem-based learning, Sosiolinguistic studies.

\section{INTRODUCTION}

In the field of linguistics, sociolinguistic studies are studies of interest, especially by students. It can be seen from sociolinguistic studies that have been carried out, both as final assignments and student assignments. One example of this can be seen from the student journal, which results from a final project or thesis. Of the 51 linguistic articles in one volume of journals numbered 16, 23 articles whose studies are sociolinguistic. That means $45 \%$ of articles are sociolinguistic studies.

The problem is, not all of these articles present the results of the analysis well. Most of the analysis is done by adjusting the data to the theory. As a result, the resulting conclusions cannot describe the answer to the problem clearly. It is certainly not in accordance with the methods contained in sociolinguistic studies. The data analysis method in sociolinguistic studies is not just an adjustment or matching of data with theory but consists of several stages: data classification, analysis, and inference [1]. Sociolinguistic studies can also be done quantitatively with various variables [2]. For example, a study conducted by Burusphat [3] used survey techniques.
One way to overcome this problem is problem-based learning. This is based on Kim's research [4] which shows that problem-solving skills have a positive effect on innovation behavior and students' perception of opportunities. In line with that, the results of Siregar's research [5] show that a problem-solving approach can improve English learning outcomes. Based on this, problem-based learning is considered to be a solution to the problem of textbook style analysis in student journal articles.

\section{METHODS}

Data collection methods used are documentation and observation. The data sources are student articles from four journals published in 2021 as well as 40 students who program sociolinguistics courses. Data analysis was carried out quantitatively to compare the analysis of the textbook style contained in the journal articles and the results of observation of problem-based learning conducted in the sociolinguistic class. 


\section{RESULTS AND DISCUSSION}

\subsection{Textbook Style Analysis}

In the introduction, it has been stated that the analysis that students tend to do is adjust the data to the theory. In this paper, this style of analysis is called textbook style analysis. The mention is based on the similarity of giving examples in sociolinguistic textbooks, mainly sociolinguistic-Indonesian textbooks.

"Kunci mengacu pada cara, nada, atau jiwa tindak tutur dilakukan. Kunci itu kira-kira serupa .... Bedakan kedua ungkapan berikut dari seorang Ibu kepada anaknya yang nakal”.

a) Kaти ini kok nakal lagi, nakal lagi,...

b) Kamu ini kok nakaaaaaalll terus ....

Pemanjangan vokal pada kata nakal pada suku kata kedua, terasa lebih ekspresif, nadanya menunjukkan kejengkelan yang memuncak" [6].

Translation:

"Key refers to the way, tone, or spirit of the speech act. The key is roughly the same.... Distinguish the following two expressions from a mother to her naughty child".

a) How come you are naughty again, naughty again,...

b) Why are you kidding all the time....

The lengthening of the vowels in the word naughty in the second syllable feels more expressive, the tone shows peaking annoyance" [6].

Compare this with the analysis in the following student journal article.

(1) "Renaldi: terus iki mas, aku denger Mendoan iku banyak diksi sing Suroboyo banget. Koyok tak pongor, iku lucu kan. Terus lek misal wong gak paham ngunu yoopo mas? (79/frs-7/akupukul/14) Berdasarkan proses pembentukannya, pisuhan tak pongor merupakan pisuhan bentuk frasa karena terdiri dari kata dan tidak memiliki ciri-ciri klausa. Pisuhan tak pongor berasal dari bahasa Jawa yang memiliki arti aku pukul. Pisuhan tersebut dituturkan ketika bintang tamu podcast Mendoan menanyakan penggunaan bahasa yang digunakan podcast Mendoan saat siaran” (data 14).

Translation:

"Renaldi: go ahead, brother, I heard "Mendoan" has a lot of dictions from Surabaya, for instance "tak pongor" it's so funny, right? Then, for example, people do not understand "ngunu, yoopo, bro?" (79/frs-7/akukul/14) Based on the process of its formation, curse word of "tak pongor" is a phrase form. It is because it consists of words and does not have clauses. The curse word "tak pongor" comes from the Javanese language which means "I hit". The curse word was said when the guest star of the Mendoan podcast asked the language used by the Mendoan podcast when broadcasting" [data 14].

The analytical model in that example is often found in student sociolinguistic studies. Based on the four journals used as data sources, textbook-style analysis tends to be used in sociolinguistic studies. This can be seen in Figure 1 below.

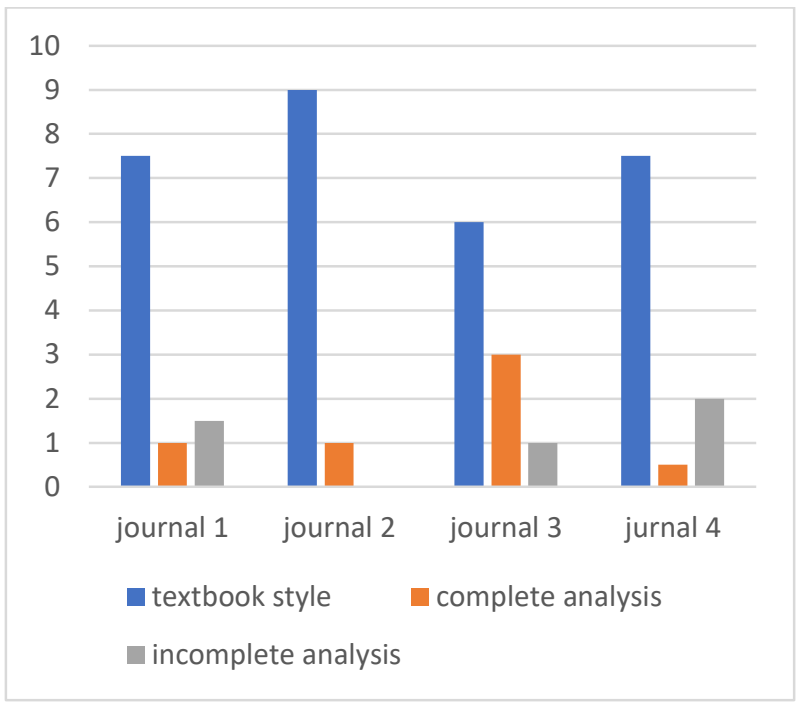

Figure 1 Comparison of sociolinguistic analysis in student articles

The number of articles for each journal is shown in Figure 1, there are 20 sociolinguistic articles taken randomly, regardless of content. Based on figure 1, it can be seen that the analysis carried out in the sociolinguistic article is a textbook-style analysis. That means, in the results and discussion section, only the definitions are presented along with examples of data. There is no basic explanation for determining the category. It can be seen in the following example.

(2) "Bahasa slang merupakan ragam bahasa yang mempunyai keunikan dan menyimpang dari arti yang lazim digunakan. Menurut Badudu (dalam Muslich, 2008:101) menyatakan bahwa gejala bahasa adalah suatu kejadian yang menyangkut bentuk kata atau kalimat dengan macam-macam proses pembentukannya. Dari data yang diperoleh, terdapat 3 slogan iklan yang terdapat variasi bahasa gaul. Data (7) dibayarin memiliki arti upaya memberikan atau membayari sesuatu (secara cuma-cuma) untuk orang lain. Dalam slogan iklan situs belanja tokopedia, kata dibayarin mengacu pada pemberian layanan secara cuma-cuma oleh pihak tokopedia seperti gratis ongkos kirim dan lain-lain." [data 7]. 
Translation:

"Slang is a variety of language that is unique and deviates from the commonly used meaning. According to Badudu (in Muslich, 2008: 101) states that language symptoms are events that involve the form of words or sentences with various processes of formation. From the data obtained, there are 3 advertising slogans with variations in slang. Data (7) paid for has the meaning of giving or paying for something (free of charge) for someone else. In the advertising slogan of the Tokopedia shopping site, the word paid refers to the provision of free services by Tokopedia, such as free shipping and others." [data 7].

In example (2), it can be seen that the analysis is carried out by defining slang, followed by an example, and ending by explaining the meaning of the example. An explanation of why "dibayarin" is slang is not presented. This kind of analysis is carried out from the beginning to the end of the results and discussion section.

(3) "Variasi anak suku Madura usia 5-6 tahun di Kalianak Timur yang menggunakan bahasa Indonesia ada tiga informan. Berikut ketiga informan tersebut beserta datanya: ..." (data 15)

Translation:

"There are three informants who use Indonesian language for Madurese children aged 5-6 years in East Kalianak. The following are the three informants and their data: ..." (data 15)

(4) "Percakapan di atas terjadi pada tanggal 20 Februari 2021 pukul 15.30 WIB. Pada saat itu bibi Ira yang bernama Ani sedang bermain ke rumah orang tuanya karena dirinya saat ini sudah tinggal di indekos ...." (data 15).

Tranlation:

(4) The conversation above took place on February 20, 2021 at 15.30 WIB. At that time, Ira's aunt, Ani, was playing at her parents' house because she is currently living in a boarding house...." (data 15).

The part marked (...) in example 3 presents the conversation of the observed subject. In example (4) the analysis of Indonesian variations is not explained. What is explained is the context of the conversation.

Referring to sociolinguistic studies in journal articles such as the study of code mixing [7], language mixing [8], the analysis does not merely provide examples and interpretations that tend to be subjective. There should be an overall analysis whose results are presented in full in the article. Complete analysis in sociolinguistic articles means that students carry out complete sociolinguistic analysis methods and procedures. It can be seen from the presentation of sample data in a table that represents each linguistic pattern found, produces a formulation of the linguistic pattern of the language/language variation studied and produces conclusions that answer the problem.

Incomplete analysis in sociolinguistic articles means that students carry out analytical methods and procedures but the analysis tends to be stuck on numbers. It can be seen in the following example.

(5) "Berdasarkan hasil penelitian terhadap bahasa slang yang ditemukan pada akun instagram @moodreceh.id sejumlah 51 data dengan rincian sebagai berikut: kata dasar 25, kata turunan 9, kata akronim 13, kata singkatan 3, kata reduplikasi 1."

Translation:

(5) "Based on the results of research on slang found on the Instagram account @ moodreceh.id a total of 51 data with the following details: 25 basic words, 9 derived words, 13 acronym words, 3 abbreviations, 1 reduplication words."

In addition to being stuck in calculating the number, incomplete analysis tends to include tables which are data classification tables. The comparison of the three methods of analysis results in the characteristics of textbook-style sociolinguistic analysis, as shown in Table 1 .

Based on Figure 1 and Table 1, it appears that many students have not done sociolinguistic analysis. What is done is to describe sample data, without a clear basis for determination and proper conclusions.

\subsection{Causes of Textbook-Style Analysis}

Based on observations made in sociolinguistics lectures, textbook-style sociolinguistic analysis is caused by the following

1) Lack of understanding of sociolinguistic data analysis methods and analytical procedures;

2) Misunderstanding of the example exposure in the textbook.

The two causes are interrelated. Students who do not understand the methods and procedures of data analysis tend to understand the presentation of examples in textbooks as a way of analyzing data. It can be seen from the way students are given lingual data, for example, code-mixing data. They did not classify the data in advance but were immediately presented one by one. 
Table 1. Comparison of Sociolinguistic Analysis in Student Articles

\begin{tabular}{|c|c|c|c|}
\hline \multirow[t]{2}{*}{ no } & \multicolumn{3}{|c|}{ Analysis } \\
\hline & Textbook analysis & complete & incomplete \\
\hline 1 & $\begin{array}{l}\text { The analysis exposure begins } \\
\text { with a theoretical definition } \\
\text { followed by an example of data }\end{array}$ & $\begin{array}{l}\text { The definition of theory is not } \\
\text { explained in the analysis section }\end{array}$ & $\begin{array}{l}\text { There is/no explanation of the } \\
\text { theoretical definition }\end{array}$ \\
\hline 2 & $\begin{array}{l}\text { Examples of data are listed one } \\
\text { by one, followed by an } \\
\text { explanation of the meaning }\end{array}$ & $\begin{array}{l}\text { Examples of data are presented } \\
\text { in tables that have been } \\
\text { organized according to the } \\
\text { linguistic patterns found. }\end{array}$ & $\begin{array}{l}\text { Examples of data are presented in } \\
\text { tables; there is no data organization } \\
\text { according to the pattern; tends to be a } \\
\text { data classification table }\end{array}$ \\
\hline 3 & $\begin{array}{l}\text { No linguistic } \\
\text { patterns/characteristics } \\
\text { /rules were produced from the } \\
\text { studied language/language } \\
\text { variations. }\end{array}$ & $\begin{array}{l}\text { Linguistic } \\
\text { patterns/characteristics } \\
\text { /rules are generated from the } \\
\text { language/language variations } \\
\text { studied. }\end{array}$ & $\begin{array}{l}\text { There are no linguistic } \\
\text { patterns/characteristics/rules of the } \\
\text { language/language variations studied; } \\
\text { the analysis results tend to be } \\
\text { quantitative results. }\end{array}$ \\
\hline 4 & $\begin{array}{l}\text { The conclusion does not answer } \\
\text { the problem }\end{array}$ & $\begin{array}{l}\text { The conclusion answers the } \\
\text { problem }\end{array}$ & $\begin{array}{l}\text { The conclusion does not answer the } \\
\text { problem. }\end{array}$ \\
\hline
\end{tabular}

\subsection{Solution to the Problem of Textbook Style Analysis}

Based on the two causes of textbook-style analysis problems, one solution to overcome this is problembased learning. That is, the sociolinguistic lectures conducted are oriented towards sociolinguistic issues in explaining sociolinguistic theories. It can be a solution because in problem-based learning, there is a flow of determining problems, problem analysis, meetings, and reports, presenting solutions and reflections, inferenceintegration and evaluation [9]. Problem-based learning can help students develop thinking skills, problemsolving, intellectual skills, and real experiences [10]. Thus, students can practice solving sociolinguistic problems through problem-based learning by analyzing data according to data analysis procedures. Without realizing it, students will learn how to analyze sociolinguistic data.

Based on observations made in the last five meetings, problem-based learning can improve students' understanding of sociolinguistic data analysis methods. It can be seen in the following graph.

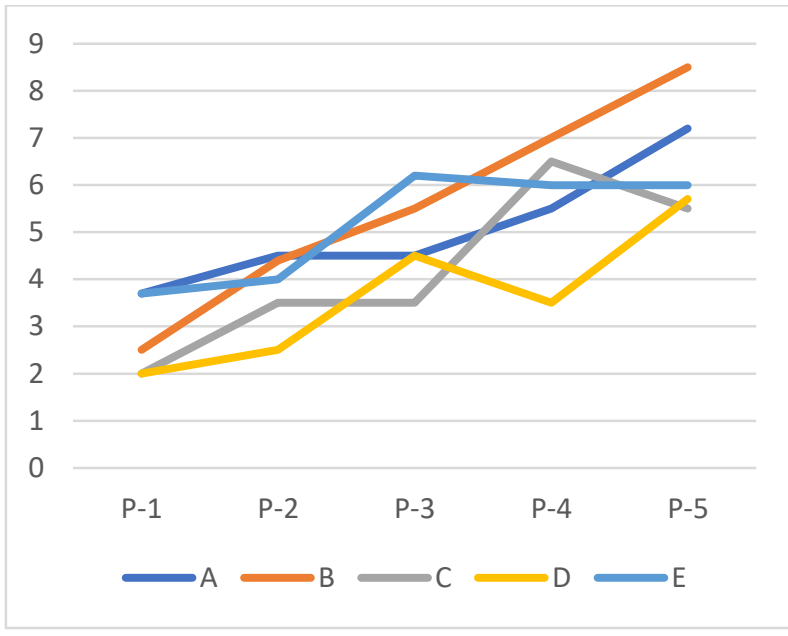

Figure 2 Problem Based Learning Observation Results

Information:

P-1 meeting 1, P-2 meeting 2, and so on.

The observations in Figure 2 were carried out on forty students who were programming the sociolinguistic course. At the beginning of the lecture (meetings 1-10), the students did not understand the material presented, especially the data analysis method. Therefore, at the 1115 meeting or the last five meetings, the learning method used was changed by first giving students problems, then observations were made to find out if there were changes for the better. The things observed were the ability to find sociolinguistic issues in the initial data (A), the ability to classify data (B), the ability to compare data (C), the 
ability to analyze according to theory (E), and the ability to conclude. The results of these observations can be seen in Figure 2, that is, students can understand sociolinguistic material better.

The results in Figure 2 is in line with the benefits of problem-based learning, namely developing thinking skills, solving problems, and developing intellectual skills [9]. Furthermore, problem-based learning in this case, can also train students to be innovative in solving sociolinguistic issues. It can be seen from the ability to classify and compare data. Each student can use different methods to reach conclusions. This innovative attitude is in line with Kim's opinion about the effect of problembased learning [4].

The benefits of problem-based learning to train students in the practice of data analysis are also seen in Sari and Prasetyo [11]. Although their study is projectbased, there are similarities between the two, namely the practice of solving problems and carrying out a project. Thus, practical activities are essential to train and improve students' ability to understand learning. In addition, other perspectives in sociolinguistic studies are also needed. Most of the student articles used a qualitative approach to examine sociolinguistic data, especially code-mixing. It seems that it is necessary to introduce various approaches to studying sociolinguistics in students, for example, integrating field and laboratory research in learning code-switching [12].

\section{CONCLUSION}

Textbook style analysis conducted by students has the characteristics of analysis exposure, beginning with the theory definition followed by data examples: the examples of data are listed one by one, followed by an explanation of the meaning, there are no linguistic patterns/ characteristics/rules of the language/language variations studied, the conclusion does not answer the problem, textbook style analysis is caused by two things. The first reason is the inability of students to understand sociolinguistic data analysis methods. The second reason is a misunderstanding that considers data exposure in sociolinguistic textbooks to analyze data. The solution to overcome the problem of textbook-style analysis is problem-based learning in sociolinguistic lectures.

\section{ACKNOWLEDGMENTS}

This study is part of a SWADANA research sourced from Unesa PNBP funds.

\section{REFERENCES}

[1] B. Suhardi, Pedoman Penelitian Sosiolinguistik, Jakarta: Pusat Bahasa Depdiknas, 2009.

[2] L. Milroy and M. Gordon, Sociolinguistics Method and Interpretation, Oxford: Blackwell, 2003.
[3] S. Burusphat, 2013. "The Language Shift in Progress of Thai Song”. Journal of the Southeast Asian Linguistics Society (JSEALS), vol. 6, p.18-34, 2013, http://hdl.handle.net/1885/9719 .

[4] J.Y. Kim, D.S. Choi , C. Sung and J. Y. Park, "The role of problem solving ability on innovative behavior and opportunity recognition in university students". Journal of Open Innovation: Technology, Market, and Complexity, vol. 4, no. 4, pp. 1-13, 2018.

https://jopeninnovation.springeropen.com/articles/1 0.1186/s40852-018-0085-4. pp.1-13.

[5] F.S. Siregar, "Improving The Result Of Learning English By Using Problem Solving Approach". Jurnal Liner, vol. 2, no. 4, pp. 61-80, 2019. http://journal.ipts.ac.id/index.php/LINER/article/vi ew/1444.

[6] S. Sumarsono and P. Partana, Sosiolinguistik, Yogyakarta: Sabda, 2002.

[7] J.Y. Shim, "Mixed Verbs in Code-Switching: The Syntax of Light Verbs," Languages, vol. 1, no. 1, pp. 1-31, 2016, https://www.mdpi.com/2226$471 \mathrm{X} / 1 / 1 / 8 / \mathrm{htm}$.

[8] B.R. Riksem, "Language Mixing and Diachronic Change: American Norwegian Noun Phrases Then and Now". Languages, vol. 2, no. 2, pp. 1-29, 2017, https://www.mdpi.com/2226-471X/2/2/3.

[9] R. Rusman, Model-Model Pembelajaran, Edisi kedua. Jakarta: Grafindo, 2014.

[10] T. Trianto, Model-Model Pembelajaran Inovatif Berorientasi Konstruktivistik. Jakarta: Prestasi Pustaka, 2007.

[11] D.M.M. Sari and Y. Prasetyo, "Project-BasedLearning on Critical Reading Course to Enhance Critical Thinking Skills," Studies in English Language and Education, vol. 8, no. 2, 2021, https://doi.org/10.24815/siele.v8i2.18407 p. 442456.

[12] A.L. Beatty-Martínez, J.R.V. Kroff and P.E. Dussias, "From the Field to the Lab: A Converging Methods Approach to the Study of Codeswitching," Languages, vol. 3, no. 2, pp. 1-19, 2018, https://www.mdpi.com/2226-471X/3/2/19. 